\author{
JOANNA GRZYBEK \\ Uniwersytet Jagielloński \\ ORCID: https://orcid.org/0000-0002-3629-9273
}

\title{
Determinanty zachowań konsumentów społeczeństwa chińskiego w ujęciu interdyscyplinarnym
}

\section{Determinants of Consumer Behavior of Chinese Society in an Interdisciplinary Perspective}

\section{Abstract}

The article aims to show that there are determinants of consumer behavior in Chinese society that remain relevant regardless of the direction of global social changes - caused by the digital transformation of society and economy, the development of artificial intelligence and unexpected events such as pandemics. The factors influencing consumption in China undoubtedly include culture, politics, as well as macroeconomic factors influencing the level and pace of consumption development. It is worth analyzing consumer behavior using interdisciplinary knowledge and bearing in mind the complex and diverse changes taking place on a national scale, and the emergence of new terminology is a reflection of the changing specificity of consumption in China.

Awareness of the dynamics of changes in the behavior of Chinese consumers will not only facilitate business relations with Chinese contractors, but will also help determine the direction of consumption development at the global level, as the possibilities of e-commerce developing in China are also used and tested in Europe.

Keywords: consumer behavior, Chinese consumers, Chinese culture, specialist Chinese language 


\section{Потребление китайского общества в междисциплинарной перспективе. Детерминанты потребительского поведения и терминология}

\section{Аннотация}

Определяющим фактором потребительского поведения, несомненно, является культура, а также макроэкономические факторы, влияющие на уровень и темпы развития потребления. Стоит понаблюдать за китайскими потребителями на фоне сложных и разнообразных изменений, происходящих по всей стране. Междисциплинарный подход в польско-китайских отношениях может положительно повлиять на развитие деловых отношений, в частности туризма, который все больше принимает модель потребления.

Ключевье слова: Китайские потребители, специализированный китайский язык

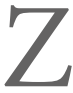
daniem Baumana (2009, s. 65) konsumowanie oznacza inwestowanie we własne członkostwo w społeczeństwie. Od chwili, gdy w dobie społeczeństwa konsumpcyjnego, przyzwyczajonego do udogodnień i swobód globalizacji, nastała pandemia, zastanawiamy się nad społecznym wymiarem kryzysu epidemiologicznego i staramy się inwestować bardziej świadomie - zarówno na poziomie gospodarstwa domowego, jak i w wymiarze globalnym. Specjaliści różnych dziedzin próbują przewidzieć zachowania ludzkie i ich konsekwencje gospodarcze. Nie są jeszcze znane wszystkie skutki ograniczeń wywołanych pandemią COVID-19, niewątpliwie jednak zmienia się ekonomiczne i psychologiczne tło konsumpcji. $Z$ dnia na dzień zgasła zyskująca w ostatnich latach na popularności turystyka konsumpcyjna. Aktualnie nie widzimy już grup chińskich turystów przyjeżdżających do Europy na zakupy. W wyniku polityki władz Chińskiej Republiki Ludowej (dalej: ChRL) markowe produkty zagraniczne sprzedawane są w Chinach w cenach wyższych niż za granicą, dlatego do niedawna Chińczycy chętnie decydowali się na zakupy poza kontynentem. Inną motywacją do zakupów w Europie była minimalizacja ryzyka podróbek (Bernat, 2016, s. 9). Ponadto wskutek wstrzymywania dostaw leków i komponentów z Chin zwrócono uwagę na potrzebę deglobalizacji oraz częściowego uniezależniania się od chińskich eksporterów. 
W tej wyjątkowej sytuacji wielu polskich przedsiębiorców mimo wszystko planuje realizację swoich celów biznesowych w Chinach, w których konsumpcja nieprzerwanie rośnie i które nadal są drugą gospodarką świata (Góralczyk, 2018, s. 282; Marszałek-Kawa, Dmochowski, 2018). W czasie „Zarazy” i kryzysu szczególnie zwraca uwagę tzw. „syntetyczna moc państwa” chińskiego, na którą oprócz wskaźników natury ekonomicznej składają się zdaniem Góralczyka (2018, s. 310): „potencjał cywilizacyjny i kulturowy państwa (w tym obowiązujący system wartości i soft power), potencjał ludnościowy, ludzki i materialny, a w ramach tego ostatniego ekonomiczny, surowcowy czy ekologiczny".

Niniejszy artykuł ma na celu wykazanie, że istnieją determinanty zachowań konsumentów społeczeństwa chińskiego, które pozostaną relewantne niezależnie od kierunku zmian społecznych w wymiarze globalnym. Transformacja cyfrowa społeczeństwa i gospodarki, rozwój sztucznej inteligencji oraz tak zaskakujące zdarzenia, jak pandemia COVID-19 zmieniają bezpowrotnie naszą rzeczywistość. Jednak to, co wyuczone zbiorowo i osadzone w duchowo-materialnym dorobku danego społeczeństwa oraz zmiany widoczne w słownictwie języka chińskiego mogą niezmiennie stanowić podstawę w poznawaniu i zrozumieniu obcej nam kultury. W związku ze zmianami gospodarczymi, prawnymi i obyczajowymi w języku następują zmiany semantyczne, w wyniku których terminy nabierają nowych znaczeń zachowując konotacje kulturowe. Rozumienie złożoności przemian rynku konsumenckiego w Chinach może być pomocne w budowaniu biznesowych relacji polsko-chińskich, a także w przewidywaniu zmian w skali globalnej.

\section{Wpływ czynników społeczno-kulturowych na zachowania konsumentów}

Cechą definiującą społeczeństwo konsumentów i kultury konsumeryzmu jest „utowarowienie” relacji międzyludzkich i poddanie ich regułom rynku towarowego (zob. Bauman, 2009). Jednak relacje w Chinach nadal determinują zachowania konsumentów. Społeczeństwo chińskie jest kolektywne, co oznacza, że grupa ma duży wpływ na jednostkę i zależność ta nie ma jedynie wymiaru materialnego, ale również mentalny (Hofstede G., Hofstede G.J., 2007, s. 135-136). Widoczna jest w tym aspekcie również koncepcja 
holistycznego porządku (整体主义zhěngtĭ zhŭyi), która dominuje w różnych dziedzinach życia - również w działaniach konsumentów, którzy łączą się w spójne, trwające w harmonii zbiorowości (Schwartz, 2009). Chiński konsument jest bardzo często powiązany relacjami z innymi i funkcjonuje w grupie, opierając się na wzajemnym zaufaniu i korzystając z doświadczeń innych konsumentów, a wspólne działalnie jest źródłem jego siły i motywacji do konsumpcji. Określenie „wspólne kupowanie” (chin. 团购 tuángòu) występuje powszechnie w tekstach branżowych i w języku potocznym.

Znaczenie autorytetu i rekomendacji bliskich lub innych zaufanych osób jest widoczne w coraz bardziej popularnej i ważnej w e-commerce działalności KOL-i ${ }^{1}$ (chin. 意见领袖 yijiàn lingxiù), czyli liderów opinii, którzy wywierają świadomie wpływ na swoich odbiorców, tj. konsumentów. Opinie takich osób są wartościowe zwykle w zakresie jednej branży i w pewnej grupie. Poparte są wiedzą i doświadczeniem w zazwyczaj określonej kategorii (Piekut, 2019). Jak zauważył Ziółek (2020), w wyniku cyfryzacji coraz bardziej zmęczony konsument jest gotowy oddać swoją prywatność w ręce algorytmów, które określają jego potrzeby zakupowe. Sieci neuronowe analizujące opinie, oceny i rekomendacje w mediach społecznościowych oraz agregacja danych na serwisach pozwalają na zdobycie informacji o aktualnych preferencjach konsumentów, jednak nie tylko te czynniki pozabranżowe mają wpływ na zachowania konsumentów i kształt branży handlowej oraz usługowej. Można założyć bowiem, że tzw. Real-Time Marketing (RTM) będzie osadzony w wartościach, którymi konsumenci i ich lider kierują się w życiu i które przekazują z pokolenia na pokolenie. Znajomość kultury konsumentów, z których rynkiem wiążemy swoje plany biznesowe, jest w dzisiejszym świecie koniecznością (Alozie, 2011), ponieważ ułatwia podejmowanie odpowiednich decyzji nie tylko w procesie tworzenia strategii marketingowych, ale również w obliczu problemów wynikających ze specyfiki branży. Kultura jako determinanta zachowań chińskich konsumentów słusznie była już przedmiotem rozważań polskich badaczy (Bernat, 2012).

Wpływ kultury na zachowania konsumentów przejawia się na przykład w tzw. zakupach grupowych (chin. 消费者组团购物 xiāofeizhě zŭtuán gòuwù), które mają w Chinach wielu zwolenników. Powstaje coraz więcej

1 KOL $-\mathrm{z}$ angielskiego 'key opinion leader'. 
specjalistycznych portali internetowych przeznaczonych do zakupów grupowych (chin. 专业团购网站 zhuānyè tuángòu wăngzhàn), a platformy zakupów grupowych (chin. 团购平台 tuángòu píngtái) są miejscem, gdzie zbierają się rodziny i przyjaciele, ale też nieznajomi, których łączy cel, jakim jest określona usługa lub produkt. Organizator grupy (chin. 开团者kāituánzhĕ; 团长 tuánzhăng) zaprasza do wspólnych zakupów osoby, które stają się członkami danej grupy zakupowej (chin. 跟团者 gēntuánzhĕ; 团员 tuányuán). Wspólnie mogą oni uzyskać produkty lub usługi po preferencyjnej cenie i na wyjątkowych warunkach. Konsumpcja grupowa w Chinach jest z pewnością warta głębszej analizy, jako że w naszej rzeczywistości tego typu zakupy nie rozwinęly się w tak znaczącym stopniu.

Sposób obchodzenia w Chinach 15 marca światowego święta World Consumer Rights Day (znanego tam jako 三一五 sānyīwŭ) świadczy o nieprzemijającym ogromnym znaczeniu w chińskim społeczeństwie socjologicznego konceptu „twarzy”' Tego dnia w chińskich mediach nagłaśnia się nieodpowiednie zachowania przedsiębiorców wobec konsumentów i nawet znane zagraniczne spółki publikują przeprosiny wobec swoich klientów, by nie tracić dobrej reputacji. Unormowania i rozwiązania cywilno-procesowe umożliwiają konsumentowi dochodzenie jego roszczeń i zmuszają producentów, sprzedawców oraz świadczących usługi do wywiązywania się z przyjętych na siebie zobowiązań. Zastosowane w ten sposób instrumenty polityki gospodarczej i społecznej mają na celu m.in. utrzymanie harmonii w relacjach gospodarczych. Chiński ustawodawca przewidział katalog różnych form rozwiązywania sporów konsumenckich (patrz: art. 39 Ustawy o prawie ochrony konsumenta ChRL). Konsument jest coraz częściej stroną $\mathrm{w}$ mediacji, która jako alternatywna forma rozwiązywania sporów pozwala na długoterminowe, bezkonfliktowe utrzymanie relacji - zarówno relacji typu $\mathrm{B}_{2} \mathrm{~B}^{2}$, ale też relacji typu $\mathrm{B} 2 \mathrm{C}^{3}$ czy $\mathrm{C}^{2} \mathrm{~B}^{4}$. W chińskim języku prawniczym pojawił się termin „mediacja konsumencka” (chin. 消费者纠纷 调解 xiāofeizhě jiūfēn tiáojiě) (Chen, 2014, s. 167). Kluczowe dla relacji biznesowych pojęcia, jak „marka” $i$ „produkt” nabrały cech antropomorficznych,

\footnotetext{
2 Ang. 'Business to business'.

3 Ang. 'Business to customer'.

4 Ang. 'Customer to business'.
} 
mówi się np. o „tożsamości marki” (chin. 品牌识别 pīnpái shíbié) i „cyklu życia produktu” (产品生命周期管理 chănpǐn shēngmìngzhōuqī guănlü) (Kochan, 2010, s. 139-175).

Decyzje chińskiego konsumenta, będącego pod wpływem coraz większej komercji i dążącego do luksusu, nie będą z pewnością podejmowane w zupełnym oderwaniu od tradycji, zorientowania na rodzinę i kultu przodków. Popularny frazeologizm „Opadające liście wracają do korzeni” (chin. 落叶 归根 luòyèguīgēn) nawiązuje do zwyczaju pochowania zmarłej bliskiej osoby w miejscu życia jej przodków. Pisał o tym Liao Yiwu (2011) w reportażu pt. Prowadzacy umarlych, a potwierdzeniem tego są wysokie ceny miejsc na cmentarzach w chińskich metropoliach, na które popyt nie maleje mimo finansowej zachęty władz do organizacji ostatniego pożegnania bliskich w morzu. Ponieważ społeczeństwo chińskie jest postfiguratywne ${ }^{5}$ wszelkie zmiany burzące wyuczony schemat następują jednak wolno. Epidemia wirusa SARS-CoV-2 przesądziła wprawdzie o decyzji Narodowej Komisji Zdrowia, dotyczącej zakazu tradycyjnych pogrzebów w Wuhan i przymusowej kremacji ciał zmarłych, jednak z pewnością nie zmieniła przekonań zakorzenionych w kulturze tradycyjnej. W chińskim języku prawnym funkcjonuje w kontekście pochówku termin 死葬 sĭzàng, a w języku prawniczym: 葬礼 zàngl̆, 丧葬 sīzàng - które to terminy kojarzą się z pochówkiem tradycyjnym, jako że morfem 葬zàng oznacza czynność „grzebania, zakopywania”.

Współczesna kultura Chin oczywiście zmienia się, przykładowo na przestrzeni ostatnich lat osłabieniu uległa tzw. męskość kultury chińskiej (Hofstede G., Hofstede G.J., 2007, s. 135-136), a podział ról społecznych kobiet i mężczyzn został zachwiany. Aktywność kobiet, nadal skupionych wokół domu i dzieci, przejawia się w poziomie konsumpcji. Właśnie ta grupa konsumentów przesądza o rosnącym zapotrzebowaniu gospodarstw domowych na produkty wysokiej jakości, bezpieczne dla dzieci i stanowiące podstawę możliwie najlepszej edukacji dla przedstawicieli pokolenia polityki jednego dziecka. Słowo „rozwój” (chin. 成长chéngzhăng) występuje w wielu reklamach produktów w odniesieniu do nauki i zdrowia (Pacześniak, 2019, s. 59). Chińskie matki decydują w dużym stopniu o zawartości koszyka

5 W społeczeństwach postfiguratywnych młodzi uczą się od starszych, a wszelkie zmiany są powolne i niemal niezauważalne (Mead, 2000). 
importowanych produktów spożywczych. Współczesna chińska rodzina wykreowała pokolenie konsumentów - jedynaków, które znacząco kształtuje rynek i niekoniecznie kieruje się zalecaną w myśl filozofii konfucjańskiej przez władze skromnością i oszczędnością (Bernat, 2012). Analiza reklam skierowanych do chińskich konsumentów może prowadzić do wniosków o „przebiegunowaniu” wartości z przeszłości na przyszłość, ze starszych na młodych, z dziadków - na dzieci. W konsekwencji polityki jednego dziecka w Chinach, wielu konsumentów to obywatele opisywani przez badaczy jako „mali cesarze” (Pacześniak, 2019, s. 64-65; Attané, 2012; Cameron, Erkal, Gangadharan, Meng, 2013, s. 953-957).

\section{Wpływ zmian systemowych na sytuację konsumentów}

Chiński ustawodawca nie precyzuje dokładnie pojęcia konsumenta (chin. 消费者 xiāofeizhĕ). Zgodnie $\mathrm{z}$ treścią ustawy o prawie ochrony praw konsumenta ChRL jest to podmiot społeczny kupujący produkty użytku codziennego i korzystający z usług (He, 2009, s. 913). Określając specyfikę chińskiego konsumenta, warto wziąć pod uwagę okoliczności kształtowania się instytucji prawnych regulujących jego uprawnienia. Chiński system prawa cywilnego ma wciąż charakter przejściowy, co wynika po części ze zmian w ustroju społeczno-gospodarczym, w zakresie form prawnych wymiany dóbr i usług oraz treści instytucji prawnych. Obowiązujące kodeksy uzupełniane są ustawami szczegółowymi. Rozdrabnianie sfery normowania stosunków cywilnoprawnych jest widoczne szczególnie w zakresie stosunków zobowiązaniowych pomiędzy konsumentem a przedsiębiorcą. Stowarzyszenie chińskich konsumentów (chin. 中国消费者协会 Zhōngguó xiāofeizhĕ xiéhui) wymienia szereg regulacji dotyczących spraw konsumenta i ochrony jego praw. Konsumpcja przenosi się coraz częściej do świata wirtualnego, nabiera charakteru międzynarodowego, dlatego potrzebne są nowe regulacje kształtujące chińskiego konsumenta. Ponadto rozwój Chin ma być oparty na wewnętrznej konsumpcji, a nie na eksporcie - jak dotychczas. Jest to efekt drugiej fazy transformacji, przejawiającej się m.in. poprzez znaczny rozwój klasy średniej (Góralczyk, 2018, s. 337).

Na rozwój ochrony konsumenta w Chinach miały wpływ przemiany systemowe, a w szczególności zmiana modelu gospodarowania. Jest to 
widoczne szczególnie w zakresie umów konsumenckich, których specyfika ewoluowała wraz z rozwojem prawa w Chinach. Zakres znaczeniowy terminu 合同 hétong, oznaczającego „umowę”, zmieniał się. Konsument jest zwykle słabszą stroną umów masowych, tj. umów przystosowanych do szybkiego i nieliczącego się zbytnio z indywidualnymi potrzebami nabywców organizowania obrotu standaryzowanych towarów i usług (Czachórski, 2007). Umowy takie upowszechniane były poprzez wzorce umowne, przybierające kształt ogólnych warunków umów, formularzy i wzory umów, regulaminów itp.). Aktualnie chiński ustawodawca przewiduje konsekwencje stosowania przez przedsiębiorców wzorców umownych (chin. 格式合同 géshì hétong $)^{6}$, które nie zostały uzgodnione indywidualnie z konsumentem, objaśnione mu na jego prośbę, a kształtują jego prawa i obowiązki w sposób sprzeczny z dobrymi obyczajami i/lub rażąco naruszają jego interesy. W art. 39 Prawa umów ChRL wprowadzono obowiązywanie zasady uczciwości (chin. 公平 原则 gōngping yuánzě). Rozwój ochrony praw konsumentów był skutkiem transformacji z gospodarki planowanej na gospodarkę rynkową, z gospodarki niedoboru na gospodarkę nadwyżki (He, 2009, s. 917). Zmiany prawne w Chinach wynikają po części z badań prawnoporównawczych (Mi, 2013, s. 302), a wiele instytucji prawnych zostało recypowanych.

$\mathrm{Na}$ zwiększenie się ochrony konsumenta miała jednak niewątpliwie pozytywny wpływ również transformacja społeczna, a dokładniej zmiany w mentalności społecznej. Konsumenci zdolni do samoorganizacji mogą dochodzić roszczeń w postępowaniu grupowym. Chiński ustawodawca przewidział taką możliwość w art. 47 Prawa konsumenckiego ChRL, upoważniając Chińskie Stowarzyszenie Konsumentów do występowania przed sądem w interesie wielu konsumentów. Zwiększa się też coraz bardziej znaczenie jednostki, która rozpatrywana jako konsument nabiera znaczenia w wymiarze gospodarczym. Zmiany gospodarcze i prywatyzacja przyniosły zwiększenie prywatnej konsumpcji. Ponieważ kupowane produkty są coraz bardziej zaawansowane technologicznie, ich użytkownik nie zawsze wie jak ich odpowiednio używać i naraża swoje zdrowie na szkody (He, 2009, s. 914). Niektóre rozwiązania, które występują w Polsce, jak np. upadłość konsumencka, czyli niewypłacalność osoby fizycznej nieprowadzącej działalności

${ }^{6}$ Nazywane również: 格式合同，也称定式合同,标准合同. 
gospodarczej (konsumenta) ${ }^{7}$, w Chinach pozostają jedynie w sferze rozważań, na łamach komentarzy prawnych. Coraz częściej przyjmowany model życia na kredyt i niemożność spłacania zaciągniętych kredytów skutkuje spychaniem dłużnika do szarej strefy. Postępowanie upadłościowe wobec osób nieprowadzących działalności gospodarczej (określanych często jako konsumentów) przeprowadza się po to, by rzetelni dłużnicy mogli w razie niewypłacalności powrócić do normalnego życia i podjąć legalną pracę zarobkową bez nękania egzekucją (Zedler, 2016, s. 222). W długoterminowej perspektywie jest to rozwiązanie korzystne ze społecznego punktu widzenia (Zedler, 2013, s. 23).

W związku ze zmianami prawnymi i obyczajowymi w języku następują zmiany semantyczne, w wyniku których terminy nabierają nowych znaczeń. Przykładem takich zmian jest chiński termin 破产pòchăn, używany aktualnie jako ekwiwalent angielskiego terminu bankruptcy („upadłość), pochodzącego od średniowiecznego włoskiej syntagmy banca rotta, oznaczającej dawniej połamany stół lub ławkę, przy których kupcy dobijali targu. Niektórzy z kupców nie byli w stanie zakończyć transakcji, ponieważ byli niewypłacalni i w ten sposób uzyskiwali pomoc prawną. Instytucja upadłości chroniła pierwotnie kupców z północnych Włoch, jednak z upływem czasu była recypowana do innych systemów prawnych (Zedler, 2016, s. 22-24), a aktualnie ma zastosowanie zarówno w systemie prawa polskiego, jak i chińskiego (中国社会科学院语言研究所词典编辑室编, 1996, s. 984; 法律出

7 Niewypłacalność to stan, w którym dłużnik nie jest w stanie wykonywać swoich wymagalnych zobowiązań pieniężnych (art. 11 ust. 1 p.u.n.) - np.: nie ma pieniędzy na jednoczesny zakup środków codziennego użytku oraz spłatę pożyczki. Upadłość konsumencka ma dwie zasadnicze funkcje:

1) oddłużenie niewypłacalnego konsumenta - umorzenie całości lub części długów konsumenta w stosunku do jego wierzycieli, których konsument nie jest, ani nie będzie w stanie zapłacić,

2) windykację (odzyskanie) należności od niewypłacalnego konsumenta przez jego wierzycieli.

31 grudnia 2014 roku weszły w życie przepisy zmieniające ustawę Prawo upadłościowe i naprawcze (dalej jako „p.u.n.”), w zakresie postępowania upadłościowego osób nieprowadzących działalności gospodarczej (tzw. upadłości konsumenckiej). Jest to bardzo istotna zmiana, która ułatwia możliwość składania wniosków o ogłoszenie upadłości konsumentów, a także ich ogłaszania oraz wprowadza możliwość zawarcia przez niewypłacalnych konsumentów układu ze swoimi wierzycielami. 
版社法规中心, 2013, s. 41). Chiński termin 破产 pòchăn może posłużyć jako przykład zmian językowych, dokonujących się w zakresie pola semantycznego terminów prawnych równocześnie ze zmianami społecznymi, gospodarczymi i politycznymi.

Pochodzenie chińskiego terminu 破产pòchăn, oznaczającego „upadłość”, nie jest oczywiste. Wiadomo, że znaki 破 pò i 产 chăn funkcjonowały osobno w tekstach klasycznych (说文解字, 2006, s. 330; He, 2009, s. 809). Zdaniem $\mathrm{He}$ (2009, s. 809) termin 破产 wystąił w Zapiskach historyka Sima Qian i oznaczał „całkowitą utratę majątku”. W wyniku recepcji prawa z Zachodu pod koniec XIX wieku i na początku XX wieku do języka chińskiego zapożyczano ${ }^{8}$ - w dużym stopniu z języka japońskiego - terminy prawne, wśród których znalazł się termin 破产 $\mathrm{w}$ znaczeniu upadłości. Jak zauważa He (2009, s. 810) w XIX wieku w kontekście upadłości używano innych dwóch terminów, tj. 拆本chāibĕn i 败盆 bàipén. Jeszcze w okresie reform Deng Xiaopinga wspierano jedynie przedsiębiorstwa państwowe, które w razie niewypłacalności otrzymywały pożyczki z banków.W 1986 roku w Chinach zaczęło obowiązywać Prawo upadłościowe ChRL (中华人民共和国企业 破产法 Zhōnghuá Rénmín Gònghéguó pòchănfă). Termin 破产 dotyczył wówczas jedynie ochrony państwowych osób prawnych (chin. 国有企业 法人 guóyǒu qŭyè fărén) (Liu, 2013, s. I). Wraz z rozwojem gospodarczym i otwieraniem się Chin na świat instytucja upadłości objęła również przedsiębiorstwa, które nie były własnością państwa (chin. 非国有企业法人 fēiguóyŏu qŭyè fărén). Zmiany te były skutkiem przystąpienia Chin do Światowej Organizacji Handlu (WTO) oraz przemian ekonomicznych. Od 2006 roku obowiązuje nowe Prawo upadłościowe (中华人民共和国企业破产法 Zhōnghuá Rénmin Gònghéguó pòchănfă) (Liu, 2013, s. I-II), które ma na celu utrzymanie porządku socjalistycznej gospodarki rynkowej. Choć instytucja upadłości, z którą wiązany jest termin 破产, nie chroni aktualnie chińskiego konsumenta będącego osobą fizyczną, to jest to temat będący przedmiotem dyskusji (Steele et al., 2018), na co wskazują również kolokacje dotyczące upadłości konsumenta (chin 消费者破产 xiāofeizhĕ pòchăn) i upadłości

${ }^{8}$ Jak wyjaśnia Cao (2004, s. 165) przyczyną zapożyczeń z języka japońskiego były wspólne tradycje językoznawcze i prawne łączące Japonię i Chiny, a także potrzeba modernizacji obu społeczeństw i powodzenie w westernizacji japońskiego prawa. 
osoby fizycznej (chin. 自然人的破产 ziránrén de pòchăn; 个人破产 gèrén pòchăn) (He, 2009, s. 814; 法律出版社法规中心, 2013, s. 7; Liu, 2013, s. 32).

\section{Podsumowanie}

Interdyscyplinarna analiza konsumpcji w Chinach umożliwia całościowe ujęcie sylwetki potencjalnego chińskiego konsumenta, który stać się może klientem polskich przedsiębiorstw. Na rozwój chińskiej konsumpcji miały wpływ, podobnie jak w Polsce, przemiany systemowe, tj. ustrojowe, gospodarcze i społeczne. Terminologia dotycząca konsumpcji w Chinach i jej analiza diachroniczna stanowią odzwierciedlenie złożoności tego tematu, jako że zakres semantyczny wielu terminów jest zależny od czasu i okoliczności ich użycia. W związku ze zmianami prawnymi i obyczajowymi w języku następują zmiany semantyczne, $w$ wyniku których terminy nabierają nowych znaczeń.

Dobra konsumpcyjne wymagają dużej adaptacji do upodobań przedstawicieli danej kultury, a świadomość różnic w zwyczajach konsumpcyjnych jest kluczowa w strategiach marketingowych i produkcji na eksport (zob. Gesteland, 2000, s. 116-117). W celu uzyskania pełnego obrazu występujących już i prognozowanych zmian w zakresie konsumpcji warto zwiększyć świadomość złożoności procesów, które zaszły w Chińskiej Republice Ludowej w przeszłości. Uzyskamy w ten sposób pełen obraz chińskiego konsumenta. Warunkiem należytego zrozumienia konsumentów w Chinach jest niewątpliwie znajomość kulturowego i historycznego kontekstu rozwoju tego kraju, a najlepiej również języka chińskiego. Warte uwagi są też czynniki polityczne, ekonomiczne i społeczne, które były źródłem zmian systemowych zarówno w Chinach, jak i w Polsce, a przez to są wspólnym mianownikiem kształtowania się sylwetki polskiego i chińskiego konsumenta.

\section{DR HAB. JOANNA GRZYBEK}

Zakład Japonistyki i Sinologii

Instytut Orientalistyki

Uniwersytet Jagielloński

al. Mickiewicza 9, 31-120 Kraków

joanna.1.grzybek@uj.edu.pl 


\section{Bibliografia}

Alozie, E.C. (2011). Advertising in Developing and Emerging Countries: The Economic, Political and Social Context. London: Routledge.

Attané, I. (2012). Tam gdzie dzieci sa luksusem: Chiny wobec katastrofy demograficznej. Warszawa: Wydawnictwo Studio Emka.

Bauman, Z. (2009). Konsumowanie życia. Kraków: Wydawnictwo Uniwersytetu Jagiellońskiego.

Bernat, M. (2016). Zmiany w konsumpcji społeczeństwa chińskiego na początku XXI wieku. W: L. Karczewski, H. Kretek (red.). Kulturowe i etyczne aspekty gospodarki, biznesu i zarzadzania. Opole: Wydawnictwo PWSZ w Raciborzu.

Cameron, L., Erkal, N., Gangadharan, L., Meng, X. (2013). Little emperors: behavioral impacts of China's One-Child Policy. Science, 339 (6122), 953-957.

Cao, D. (2004). Chinese Law: A Language Perspective. Clevedon: Multilingual Matters Ltd.

Chen, Z. (red.). (2014). 诉讼调解. 北京: 法律出版社.

Czachórski, W. (2007). Zobowiązania. Zarys wykładu. Warszawa: Lexis Nexis.

法律出版社法规中心. (2013). Prawo upadłościowe Chińskiej Republiki Ludowej z komentarzem - 中华人民共和国消费者权益保护法注释本，北京.

Gesteland, R. (2000). Różnice kulturowe a zachowania w biznesie. Warszawa: Wydawnictwo Naukowe PWN.

Góralczyk, B. (2018). Wielki renesans. Chińska transformacje i jej konsekwencje. Warszawa: Wydawnictwo Akademickie Dialog.

$\mathrm{He}$, Q. (2009). 法律名词的起源, 北京：北京大学出版 社.

Hofstede, G., Hofstede, G.J. (2007). Kultury i organizacje: Zaprogramowanie umysłu. Warszawa: Polskie Wydawnictwo Ekonomiczne.

Kochan, M. (2010). Mówiony język biznesu. W: M. Milewska-Stawiany, E. Rogowska-Cybulska (red.). Polskie języki. O językach zawodowych i środowiskowych. Materiały VII Forum Kultury Stowa Gdańsk, 9-11 października 2008 roku. Gdańsk: Wydawnictwo Uniwersytetu Gdańskiego, 139-175.

Liao, Y. (2011). Prowadzący umarlych. Opowieści prawdziwe. Chiny z perspektywy nizin społecznych. Warszawa: Wydawnictwo Czarne.

Liu, M. (2013). 破产法学：基本原理与立法规范. 北京：华中科技大学出版社.

Marszałek-Kawa, J., Dmochowski, T. (red.). (2018). Rozważania o kierunkach współczesnej polityki Chin. Toruń: Wydawnictwo Adam Marszałek.

Mead, M. (2000). Kultura i tożsamość: studium dystansu międzypokoleniowego. Warszawa: Wydawnictwo Naukowe PWN.

Meyer, M. (2012). Kulturowa sylwetka chińskiego konsumenta. Praktyczne implikacje dla marketingu. Marketing i Rynek, 2.

Mi, J. (2013). 比较法学导论. 北京：商务印书馆.

Michalski, E. (2017). Marketing: podręcznik akademicki. Warszawa: Wydawnictwo Naukowe PWN.

Pacześniak, J. (2019). Reklama a kultura. Cechy tradycyjnej chińskiej rodziny we wspótczesnej reklamie wideo $w$ Internecie. Praca magisterska napisana pod kierunkiem $d r$ hab. Joanny Grzybek. Kraków: Uniwersytet Jagielloński. 
Piekut, M. (2019). KOL, czyli niezbędny element e-commerce w Chinach. Część 5 przewodnika po e-commerce $w$ Chinach. Pobrane z: https://www.wnp.pl/rynki-zagraniczne/ kol-czyli-niezbedny -element-e-commerce-w-chinach-czesc-5-przewodnika-po-e-commerce,339587.html.

Schwartz, B.I. (2009). Starożytna myśl chińska. Kraków: Wydawnictwo Uniwersytetu Jagiellońskiego.

Settles, B.H., Sheng, X., Zhang, Y., Zhao, J. (2013). The one-child policy and its impact on Chinese families. W: K. Chan (red.). International handbook of Chinese families. New York: Springer, 627-646.

Zedler, F. (2016). Zarys prawa upadłościowego. Warszawa: Wolters Kluwer.

Zhuang, J. (2020). Can non-Chinese KOLs ever threaten local leaders' market dominance? Pobrane z: https://jingdaily.com/luxury-tap-foreign-kols-china/.

Ziółek, B. (2020). Czego o konsumencie moga nas nauczyć Chińczycy? Pobrane z: https://handelextra.pl/artykuly/236172,czego-o-konsumencie-moga-nauczyc-nas-chinczycy.

中国社会科学院语言研究所词典编辑室编 (1996). 法律出版社法规中心. Ustawa o prawie upadłościowym Chińskiej Republiki Ludowej z komentarzem - 中华人 民共和国消费者权益保护法注释本, 北京 2013 .

中华人民共和国合同法. Ustawa o prawie umów Chińskiej Republiki Ludowej z 13.03.1999 r. (z późn. zm.).

中国消费者协会 Chińskie Stowarzyszenie Konsumentów. (2020, 2 lutego). Pobrane z: http://www.cca.org.cn/wqfg/list/25_2.html. 